\title{
Consumer Skepticism regarding Cause Marketing - An analysis
}

\author{
Ancy Raja Nathiya $\mathbf{M}^{\mathbf{1}}$, Asha $\mathrm{K}^{\mathbf{2}}$ \\ Research Scholar, Department of Management Studies, Noorul Islam Centre for Higher Education, Kumaracoil ${ }^{1}$ \\ Assistant Professor, Faculty of Management Studies, Noorul Islam Centre for Higher Education Kumaracoil ${ }^{2}$
}

\begin{abstract}
Nowadays, consumers are more skeptical towards the marketer's activities. They were unable to trust the marketer's tactics. Cause marketing is widely used by the marketers to create a unique social platform for them to create positive impact among the consumers. Many countries have adopted this for a cordial relationship between the corporates and consumers. The purpose of the study is to find out the factors influencing consumer skepticism towards cause marketing and to give insights to the marketers about the concept. The key ingredients for the rise of skepticism are that consumers were lack in awareness and knowledge about cause marketing practices. Hence, an attempt is made to investigate about consumer skepticism regarding cause marketing. Statistical analysis was done with the collected data from 100 consumers. As a result, it is found out as, proper spread of awareness and concept knowledge may reduce the possibilities of consumer skepticism.
\end{abstract}

Keywords-Cause marketing, Consumer Skepticism, Campaigns

\section{INTRODUCTION}

Cause marketing is a term which was first coined by "American Express" in 1983, for the purpose of collecting fund for the restoration of 'Statue of Liberty'. They donate one cent to the restoration purpose for every single use of the card. The concept begins from this event. Cause marketing is a kind of effort executed by both the non-profit and profit organization in collaboration with a cause for doing their corporate social responsibility. It is a legalized norm for the firm to fulfil their organizational objective as well as doing good for the society. Cause marketing is considered to be a tool for every organization to fulfil this norm. Cause marketing provides benefits for both the profit and non-profit organizations. The corporate will enjoy the good will and the charities do get financial support. For this purpose, a cause marketing campaign will be conducted by the marketer. The aim of the campaign is to create awareness on the particular cause and gets donation for the charities. This would highly help in optimizing goodwill, increasing customer loyalty etc. Customers are more attracted towards the brand which are socially responsible. Such brands will get a positive identity.

\subsection{Types of Cause Marketing}

Cause marketing strategies can be done in various forms and few are stated below:

a) Message Oriented Campaigns:

Through the promotional campaign conducted by the organization. The corporates create awareness about the social cause and deliver the message.

b) Transactional related Campaigns:

Here, the cause which has chosen will get triggered by the consumer actions and it helps the company to give contribution for it.

c) Digital Oriented Campaigns:

Here, the corporates uses the digital platform to spread the awareness and raise donations for the charities.

d) Sales Oriented Campaigns:

The campaigns are focused on the point of sales, which makes the customer to donate for the particular

cause.

e) Cause related Campaigns:

It has done jointly by both the 'for profit' and 'non-profit' organization in the way known as, on purchase of the particular product a certain amount will be forwarded to the charities by corporates. 


\section{International Advanced Research Journal in Science, Engineering and Technology}

Vol. 8, Issue 9, September 2021

DOI: 10.17148/IARJSET.2021.8910

\section{LITERATURE REVIEW}

\subsection{Cause marketing}

Mary Runte, Debra Z.Basil and Sameer Deshpande (2009), says that, with quantitative and qualitative methods this research has done from the perspective of non-profit. US NPO managers $(n=154)$ were participated and it has resulted as, both the first \& second order outcome goals (immediate financial support) and (less tangible for longer term) were met while understanding CRM. It seeks networking opportunities, event support and public awareness with finding opportunities.

Sridhar Samu and Walter Wymer (2013), in their article reveals that, fit (high/low) and salience (brand vs cause) were the key moderators on the type of message (information/buy) from the consumer's responses. When they are salient, they can use buy message, this benefits only when fit is high. And, when cause use informational messages, salience leads the outcomes to be positive, only if the fit is low. As a result, it suggest ways for both brand and cause to be on a win-win situation.

Donald P. Roy (2010), portrays that, the aim of the paper is to examine the relationship between the response of consumer to cause related marketing programs and sponsor-cause congruence. It also aims to analyse the consumer response on service type of a cause sponsor and the possible existence of interaction of congruence. It resulted as, the congruence service type interaction are significant.

Anne M. Lavack and Fredric Kropp (2003), expresses that, the research has undertaken across four countries (ie) Australia, Canada, Korea and Norway. It investigates the role of consumer attitudes towards cause related marketing and found out as, the attitude level varies across countries. Cause related marketing is find to be less positive where it was established less (eg.Korea). On the other hand, CRM is more positive where it is established more (eg.Canada). The difference in attitude also directly correlated with personal, internal and external values.

\subsection{Consumer Skepticism on Cause Marketing}

Mohr, Eroglu and Eleen (1998), found out as, consumer skepticism is referred as a tendency of consumer either to question or disbelieve the company towards motivating them to conduct a cause marketing program.

Webb and Mohr (1998), opines that, an attachment of the statement regarding the money donated for a particular cause is disclosed, to reduce the doubts raised by the consumers about the promised fact, "Is the amount is correctly donated to a particular cause or not".

Gupta and Pirsch (2006), suggests that, consumers purchase intention is not fully influenced by consumer skepticism and they do perceive the aim of the campaigns conducted by the corporates as altruistic one and willing to make their purchase towards cause related products.

Bronn and Vrioni (2001), suggests that, repeating the claims regarding cause marketing and a proper awareness about the cause marketing can help to reduce the consumer skepticism level and helps to enhance the purchase intention of the consumers regarding the cause oriented products.

\section{METHODOLOGY}

\subsection{Objectives of the study}

The study has been undertaken to investigate the following objectives:

- $\quad$ To study the level of awareness and knowledge among consumers regarding cause marketing.

- $\quad$ To understand the perception of consumer about cause marketing practices.

- To identify the factors influencing consumer skepticism regarding cause marketing.

- $\quad$ To offer suggestions basis on the study.

\subsection{Sample and Methods}

The sample population for the study were 100 respondents across Kanyakaumari District. A convenience sampling method has been used. Data were collected by using a structured questionnaire method. Most of the questionnaire were sent through mails due to the pandemic reason and few are collected manually. A brief note about cause marketing along with a ad video regarding cause marketing has been attached with the questionnaire. 


\section{RESEARCH FINDINGS}

Findings are considered to be the result of the study and the collected data are valued using few statistical tools to find out the result to give suggestion based on the proposed study.

Table.1. Characteristics of Respondents $(\mathrm{N}=\mathbf{1 0 0})$

\begin{tabular}{|l|l|l|}
\hline Categories & Particulars & Percentage \\
\hline \multirow{4}{*}{ Gender } & Male & 59 \\
\cline { 2 - 3 } Age & Female & 41 \\
\hline \multirow{4}{*}{ Area } & 18 yrs -29 yrs & 35 \\
\cline { 2 - 3 } & 30 yrs -45 yrs & 41 \\
\cline { 2 - 3 } Educational & Above 46 yrs & 24 \\
\hline \multirow{2}{*}{ Qualification } & Urban & 77 \\
\cline { 2 - 3 } & Rural & 23 \\
\cline { 2 - 3 } & Schooling & 18 \\
\cline { 2 - 3 } & UG & 53 \\
\cline { 2 - 3 } & PG & 29 \\
\hline
\end{tabular}

Table 1 reveals that $59 \%$ of the respondents are male and $41 \%$ are females. Most of the respondents $(41 \%)$ are around $30-45 \mathrm{yrs}, 35 \%$ are with $18-29$ yrs and $24 \%$ are above 46 yrs. The area highly focused for the study are Urban with $77 \%$ and rural with $23 \%$. Respondents with $18 \%$ are done with their schooling, $53 \%$ are under graduates and 29 are Post graduates.

Table.2. Consumer's level of awareness and knowledge about cause marketing

\begin{tabular}{|l|l|l|}
\hline Categories & Particulars & Percentage \\
\hline $\begin{array}{l}\text { Can recall the advertisement } \\
\text { regarding cause marketing }\end{array}$ & Yes & 42 \\
\cline { 2 - 3 } & No & 58 \\
\hline Have heard the concept cause & Yes & 12 \\
\cline { 2 - 3 } marketing in any way & No & 88 \\
\hline \multirow{2}{*}{$\begin{array}{l}\text { Up to date self-involvement about } \\
\text { the contributions towards Causes }\end{array}$} & High & 77 \\
\cline { 2 - 3 } $\begin{array}{l}\text { Opinion about donating for a good } \\
\text { cause }\end{array}$ & Gow & 23 \\
\cline { 2 - 3 } & Bad & 100 \\
\hline
\end{tabular}

Table 2 reveals that, $42 \%$ of the respondents have seen cause marketing related advertisements, where $58 \%$ are have not seen. Respondents of $88 \%$ have not heard about the concept earlier, where $12 \%$ of them stated as they have heard. $77 \%$ of the respondents stated as, till date they are highly involving themselves towards the contributions for causes, where $23 \%$ of them never get involved in such activity. But all the respondents are having a good opinion for donating a good cause.

Table.3. Consumer Perception about cause marketing

\begin{tabular}{|c|c|c|c|c|c|c|c|c|}
\hline Characteristics & SA-5 & A-4 & $\mathrm{N}-3$ & D-2 & SD-1 & Total & $\begin{array}{l}\text { Weighted } \\
\text { Average }\end{array}$ & Rank \\
\hline $\begin{array}{l}\text { Cause } \\
\text { marketing is a } \\
\text { good idea }\end{array}$ & $\begin{array}{l}43 \\
{[215]}\end{array}$ & $\begin{array}{l}36 \\
{[144]}\end{array}$ & $\begin{array}{l}18 \\
{[54]}\end{array}$ & $\begin{array}{l}3 \\
{[6]}\end{array}$ & $\begin{array}{l}- \\
{[49]}\end{array}$ & 468 & 31.2 & 1 \\
\hline Trustworthy & - & - & $\begin{array}{l}8 \\
{[24]}\end{array}$ & $\begin{array}{l}74 \\
{[148]}\end{array}$ & $\begin{array}{l}18 \\
{[18]}\end{array}$ & 190 & 12.67 & 6 \\
\hline $\begin{array}{l}\text { State of } \\
\text { dilemma to go } \\
\text { with either good } \\
\text { or bad }\end{array}$ & $\begin{array}{l}27 \\
{[135]}\end{array}$ & $\begin{array}{l}10 \\
{[40]}\end{array}$ & $\begin{array}{l}23 \\
{[69]}\end{array}$ & $\begin{array}{l}40 \\
{[80]}\end{array}$ & - & 324 & 21.6 & 4 \\
\hline
\end{tabular}


DOI: 10.17148/IARJSET.2021.8910

\begin{tabular}{|l|l|l|l|l|l|l|l|l|}
\hline $\begin{array}{c}\text { corporates are } \\
\text { highly benefited }\end{array}$ & 21 & 11 & 16 & 15 & 37 & 264 & 17.6 & 5 \\
{$[105]$} & {$[44]$} & {$[48]$} & {$[30]$} & {$[37]$} & & & & \\
\hline $\begin{array}{l}\text { Society get } \\
\text { more benefits \& }\end{array}$ & {$[135]$} & {$[100]$} & {$[120]$} & {$[16]$} & 37 & 371 & 24.73 & 3 \\
\hline $\begin{array}{l}\text { Both society \& } \\
\text { Company get } \\
\text { equal benefits }\end{array}$ & 54 & 37 & 6 & 3 & - & 442 & 29.5 & 2 \\
\hline
\end{tabular}

Table 3 reveals that, the respondents do give higher weightage for cause marketing as a good idea with a mean score of 31.2, ranked 1, where they believe it as beneficial for both the parties is ranked as 2 with a mean score of 29.5. Respondents feel as the society gets more benefit through cause marketing and ranked as 3 with a mean score of 24.73, where few are at a dilemma to give a good suggestion about cause marketing and ranked it as 4 with a mean score of 21.6. The respondents never supports as the cause marketing practice is done for publicity of the corporates and ranked it as 5 with a mean score of 17.6 and also they are strongly disagree with the point when it comes for trust and ranked last with a mean score of 12.67 .

Table.4. Factors influencing consumer skepticism about cause marketing

\begin{tabular}{|c|c|c|c|c|c|c|c|c|}
\hline $\begin{array}{l}\text { Characteristi } \\
\text { cs }\end{array}$ & SA-5 & A-4 & N-3 & D-2 & SD-1 & Total & $\begin{array}{l}\text { Weighted } \\
\text { Average }\end{array}$ & Rank \\
\hline $\begin{array}{l}\text { Marketing } \\
\text { tactics }\end{array}$ & $\begin{array}{l}89 \\
{[445]}\end{array}$ & $\begin{array}{l}5 \\
{[20]}\end{array}$ & $\begin{array}{l}6 \\
{[18]}\end{array}$ & - & - & 483 & 32.2 & 1 \\
\hline Sales focused & $\begin{array}{l}59 \\
{[295]}\end{array}$ & $\begin{array}{l}36 \\
{[144]}\end{array}$ & $\begin{array}{l}5 \\
{[15]}\end{array}$ & - & - & 454 & 30.3 & 3 \\
\hline $\begin{array}{l}\text { Low Trust } \\
\text { Propensity }\end{array}$ & $\begin{array}{l}20 \\
{[100]}\end{array}$ & $\begin{array}{l}68 \\
{[272]}\end{array}$ & $\begin{array}{l}12 \\
{[36]}\end{array}$ & - & - & 408 & 27.2 & 5 \\
\hline $\begin{array}{l}\text { Replacing the } \\
\text { grievances }\end{array}$ & $\begin{array}{l}1 \\
{[205]}\end{array}$ & $\begin{array}{l}33 \\
{[132]}\end{array}$ & $\begin{array}{l}26 \\
{[78]}\end{array}$ & - & - & 415 & 27.67 & 4 \\
\hline For Publicity & $\begin{array}{l}83 \\
{[415]}\end{array}$ & $\begin{array}{l}13 \\
{[52]}\end{array}$ & $\begin{array}{l}4 \\
{[12]}\end{array}$ & - & - & 479 & 31.93 & 2 \\
\hline
\end{tabular}

Table 4 reveals that, the respondents feel it as a marketing tactics and ranked as 1 with a mean score of 32.2 , where the respondents gave $2^{\text {nd }}$ rank for the publicity with a mean score of $31.93 .3^{\text {rd }}$ is for sales focused with a mean score of 30.3 , where replacing the grievance is given $4^{\text {th }}$ rank by the respondents with a mean score of 27.67. And the last rank is provided to the low trust propensity with a mean score of 27.2.

\section{DISCUSSION \& SUGGESTIONS}

The result of the study suggests that consumers are not much aware about the concept cause marketing and have no knowledge regarding this. Many are not even able to recall any advertisements about cause marketing. This suggest as, consumers should aware about the concept cause marketing to gain good opinion about the activity. It is requested to spread enough knowledge about this practice among consumers. Few consumers never involve them in any donations but many have shown interest towards monetary contributions. On the other hand, all the consumers feel like donating for a good cause is definitely a good option to do some betterment to the society. It is advised to, spread enough awareness and knowledge among consumer to stop being skeptical. Consumers also perceive cause marketing as a good idea and they believe that both the corporate and society gets benefited in a balanced manner by implementing cause marketing. They do view cause marketing practice is highly beneficial for the society comparing the business organization. Few of the respondents are also in a dilemma to accept cause marketing in a good way and have trust issues regarding the cause marketing practices done by the company. Also, the factors which influences the cause marketing practices are marketing tactics, sales focused, low trust propensity, replacing the grievances and publicity. 


\section{International Advanced Research Journal in Science, Engineering and Technology}

Vol. 8, Issue 9, September 2021

DOI: 10.17148/IARJSET.2021.8910

The study suggest as, the marketers have to take necessary step to stop consumers from being skeptical by creating awareness and spreading knowledge about cause marketing.

\section{CONCLUSION, LIMITATIONS \& SUGGESTIONS FOR FUTURE RESEARCH}

Cause marketing practices should be known to everyone to reduce consumer skepticism. As it is mandatory for every organization to involve in this activity. The marketers have to keep this into consideration and do betterment for the society as well as to increase their benefits. This study focused about the consumer skepticism regarding cause marketing and for this purpose the data were collected around Kanyakumari district. Further study can be carried out in other regions to get more information about the study. This study is an attempt on concentrating about consumer scepticism in common and hence future study can be carried out by combining a relationship analysis between the factors and demographic profile.

\section{REFERENCES}

1. S. Zdravkovic, P. Magnusson and S. M. Stanley, "Dimensions of fit between a brand and a social cause and their influence on attitudes," International Journal of Research in Marketing, vol. 27, pp. 151-160, 2010.

2. D. Kumar, H. Bansal, "Influence of cause brand fit on consumers purchase intention," International Journal of Research in Finance and Marketing, vol. 7, no. 1, pp. 99-107, 2017.

3. M. M.Anuar and O. Mohamad, "Effects of Skepticism on Consumer Response toward Cause-related Marketing in Malaysia," International Business Research, vol. 5, no. 9, 2012.

4. S. T. Ahmad, I. batool, S. A. Quarshi, A. I. Hunjra and G. S. K. Niazi, "Outcomes of Cause related Marketing: a Demographic Analysis," Middle-East Journal of Scientific Research, vol. 10, no. 2, pp. 260-269, 2011.

5. M. M. Anuar, F. Adam and O. Mohamad, "Consumer Response to Cause-related Marketing: Muslim Consumers' Perspective, vol. 4, no. 8, pp. 97-104, 2014.

6. M. M. Anuar, K. Omar and O. Mohamad, "Does Skepticism Influence Consumers Intention to Purchase Cause-related Products," International Journal of Business and Social Science, vol. 4, no. 5, 2013.

7. H. Saberi and A. R. Karsalari, "The Interactive Effects of Cause Related Marketing Campaigns, Perceptual Brand Equity Dimensions and Cultural Values on Consumer Purchase Intentions," International Journal of Academic Research in Accounting, Finance and Management Sciences, vol. 4, no.2, pp. 117-126, 2014.

8. V. Amawate and M. Deb, "Antecedents and consequences of consumer skepticism towards cause-related marketing: Gender as moderator and attitude as mediator," Journal of Marketing Communications, https://doi.org/1080/13527266.2019.1630663

9. M. Bae, "Overcoming skepticism towards cause-related marketing claims: the role of consumers' attributions and a temporary state of skepticism," Journal of Consumer Marketing, vol. 35, no. 2, pp.194-207, 2018.

10. P. N. Bloom, S. Hoeffler, K. L. Keller and C. E. B. Meza, "How Social-Cause Marketing Affects Consumer Perceptions," MITSloan Management Review, vol. 47, no. 2, 2006.

11. S. Singh, L. Kristensen and E. Villasensor, "Overcoming Skepticism towards cause related claims: the case of Norway," International Marketing Review, vol. 26, no. 3, pp. 312-326, 2009

12. K. Lee, "Consumer Skepticism about Quick Service Restaurants' Corporate Social Responsibility Activities," Journal of Foodservice Business Research, vol. 23, no. 5, pp. 417-441, 2020.

13. P. S. Ellen, L. A. Mohr and D. J. Webb, "Charitable Programs and the Retailer: Do They Mix," Journal of Retailing, vol. 76, no.3, pp. 393-406, 2000.

14. S. S. Manojkumar and M. S. Sharma, "An Empirical Study To Measure The Effect of Brand Loyalty and Skepticism on Purchase Intention with reference to Cause related Marketing in Ahmadabad City," Journal of Management, vol. 5, no. 2, pp. 1-12, 2018.

15. N. Nourozi and M. JavadTaghipourian, "Consumer Skepticism: Revision on Advertising from Behavioural Dimension," Indian Journal of Natural Science, vol. 6, no. 31, 2015.

16. M. Bae, "Effect of Skepticism and message abstractness on cause-related marketing campaign evaluation: The mediating role of message engagement," Cognent Business and Management, vol. 7, no. 1, 2020.

17. Y. J. Lee, H. Nicole, O'Donnell and S. J. T. Hust, "Interaction Effects of System-Generated Information and Consumer Skepticism: An Evaluation of Issue Support Behaviour in CSR Twitter Campaigns," Journal of Interacting Advertising, https://doi.org/10.1080/15252019.2018.1507853

18. Ajitha K; Samuel Joseph C; Mahila Vasanthi Thangam D. "Online marketing of agricultural products during COVID pandemic: Farmers and customers perspectives". International Research Journal on Advanced Science Hub, 3, Special Issue 6S, 2021, 94-101.

19. Priyanka Kumari. "A Study of Customer Preference and Attitude towards Online Shopping In Bihar". International Research Journal on Advanced Science Hub, 3, Special Issue ICEST 1S, 2021, 7-11. doi: 10.47392/irjash.2021.012 